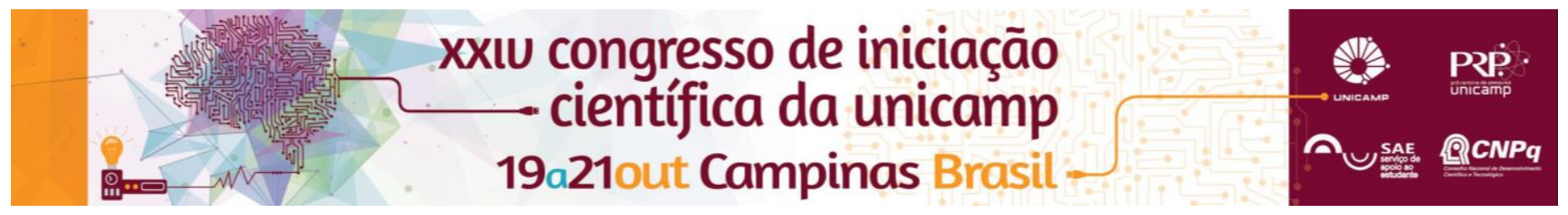

\title{
Análise do valor pós IPO das empresas nacionais e não financeiras co-geridas por fundos de private equity.
}

\section{Lidiamara de O. S. Betette.*}

\section{Resumo}

A intenção deste trabalho foi analisar as condições de desempenho e risco das empresas que tiveram financiamento de fundos de private equity (PE) após a abertura de capital, comparando-as em um estudo de evento com outras que não tiveram participação destes fundo, e assim verificar se a participação dos mesmos gera uma valorização maior das empresas.

\section{Palavras-chave}

Private Equity, Análise de cenário, Análise de retorno.

\section{Introdução}

Fundos de Private Equity (PE), são aqueles que investem em ações de empresas não listadas em mercados públicos de valores, analisadas rigorosamente e selecionadas quando estejam consolidadas no setor em que atuam, com alto potencial de crescimento e perspectivas de rentabilidade elevada; sendo que o objetivo é dar impulso financeiro à companhia, alavancar seus resultados de forma a incrementar seu valor e posteriormente prepará-la para abrir capital na bolsa de valores. Trata-se de um longo processo que requer essencialmente que gestores e investidores desses fundos juntem esforços e otimizem a gestão na tentativa de agregar valor às empresas.

Este trabalho focou-se em analisar empiricamente qual o impacto sob a perspectiva de risco e desempenho desses investimentos no valor das empresas após sua oferta pública de ações, e partir de então verificar se há alguma valorização proporcionada pelos fundos.

\section{Resultados e Discussão}

As análises foram desenvolvidas por método quantitativo, através da extração de dados na plataforma Thomson Reuters, referentes ao valor de mercado das empresas selecionadas, no período de 2009 a 2014. Sendo que as informações obtidas foram comparadas num estudo de evento a fim de se investigar o impacto que os investimentos via fundos de PE/VC têm sobre o valor das empresas.

Este estudo de evento, consiste na análise do efeito de informações específicas de determinadas empresas sobre os preços de suas ações, sendo que neste trabalho foi utilizado o software Stata, para analisar a base de dados através de métodos estatísticos.

Tamanho da empresa, setor, variáveis de resposta como: retorno sobre o patrimônio líquido, retorno sobre os ativos, Net Income, Total Equity, EBITIDA EBITDA, estão entre as variáveis utilizadas para testar a hipótese de influência dos fundos de investimento sobre o valor das empresas. O painel de dados fora submetido a diferentes testes diversificando a variável de análise, afim detectar se alguma delas se alterava significativamente quando pertencente à uma empresa co-gerida por fundos de PE/ VC anteriormente ao seu IPO.

\section{Conclusões}

Os testes realizados mostram que para as variáveis analisadas, o aporte vindo de PE/VC não reproduz resultados significativos para indicar uma valorização das empresas proveniente desses fundos.

\section{Agradecimentos}

Meus sinceros agradecimentos ao $\mathrm{CNPq}$ pela oportunidade, e ao Prof. Dr. Johan Hendrik Poker Junior pela sua disponibilidade, por prestar toda orientação e esclarecimentos necessários para execução deste trabalho; e também toda colaboração, solicitude e conhecimentos repassados.

\footnotetext{
${ }^{1}$ COPELAND, Tom; KOLLER, Tim e MURRIN, Jack. Avaliação de empresas valuation - Calculando e gerenciando o valor das empresas. São Paulo: Pearson Makron Books, 2002

2 CAMARGOS, Marcos Antônio de;BARBOSA, Francisco Vidal. Estudos de evento: Teoria e operacionalização- Caderno de Pesquisas em Administração, São Paulo, v. 10, nº 3, p. 01-20, julho/setembro 2003.

3 PAVANI, Claudia. O capital de risco no Brasil- Conceito, evolução, perspectivas. Editora E-papers, 2003.
} 